\title{
Pentingnya Penerapan Kurikulum Berbasis Penguatan Pendidikan Karakter bagi Terciptanya Generasi Emas Indonesia Tahun 2045
}

\author{
Ramses Simanjuntak \\ Sekolah Tinggi Teologi Nazarene Indonesia \\ ramsessimanjuntak@gmail.com
}

\begin{abstract}
Indonesia is a country that is so big, rich in natural resources and has cultural traditions that have been deeply rooted since time immemorial. In the age of 73 years, there have been many advancements that have been made by this country, be it progress in the fields of economics, education, welfare, health and the progress of other facilities / infrastructure. Indeed, it is undeniable that there are still many unreached and underdeveloped areas that we see, but we believe that someday all regions will feel evenly distributed social justice, where poverty, underdevelopment and ignorance will not be seen in all regions of our beloved country this. As citizens of the Republic of Indonesia, who live on this beloved earth, all elements of society should support every government program to improve the quality of Indonesian people by improving character education, so that it becomes a complete curriculum for the creation of a strong and future generation based on Pancasila.
\end{abstract}

Keywords: God, prototype, innocence, simplicity

\begin{abstract}
Abstrak: Indonesia adalah negara yang begitu besar, kaya akan sumber daya alam dan memiliki adat budaya yang mengakar kuat sejak dahulu kala. Dalam usianya yang sudah menginjak 73 tahun banyak kemajuan yang telah dirasakaan oleh negeri ini, baik itu kemajuan dalam bidang ekonomi, pendidikan, kesejahteraan, kesehatan dan kemajuan sarana/prasarana lainnya. Memang tidak dapat dipungkiri bahwa masih banyak daerah-daerah yang belum terjangkau dan tertinggal yang kita lihat, tapi kita percaya bahwa suatu hari nanti semua daerah akan merasakan keadilan sosial yang merata, dimana tidak akan terlihat lagi kemiskinan, ketertinggalan dan kebodohan di seluruh wilayah negeri tercinta ini. Sebagai warga negara Republik Indonesia, yang tinggal di bumi pertiwi tercinta ini, sudah seharusnyalah semua elemen masyarakat mendukung setiap program pemerintah untuk meningkatkan mutu manusia Indonesia dengan cara meningkatkan pendidikan karakter, sehingga menjadi satu kurikulum yang utuh bagi terciptanya generasi penerus bangsa yang kuat dan berazaskan Pancasila.
\end{abstract}

Kata Kunci: Kurikulum, Pendidikan Karakter, Generasi Emas

\section{Pendahuluan}

Indonesia sebagai negara kepulauan memiliki potensi kekayaan alam yang luar biasa, kedepannya negeri ini harus dipimpin oleh para generasi bangsa yang berkarakter unggul, karena dengan karakter yang unggul seperti itulah Indonesia akan jaya menuju masyarakat yang adil dan makmur (gemah ripah loh jinawi), sebab jika generasi muda bangsa ini tidak 
di didik dengan karakter yang mulia niscaya bangsa ini akan hancur, seperti apa yang dikatakan oleh Thomas Lickona yang dikutip oleh Agus Wibowo dalam bukunya yang berjudul Pendidikan Karakter: Strategi Membangun Karakter Bangsa Berperadaban yang berkata: "sebuah bangsa sedang menuju kehancuran, ketika karakternya tergadai"1

Socrates berkata bahwa tujuan paling mendasar dari pendidikan adalah untuk membuat seseorang menjadi good and smart. ${ }^{2}$ Sedangkan Alkitab sebagai Firman Allah yang menjadi petunjuk dasar kehidupan orang Kristen berkata dalam Amsal 22:6, "Didiklah orang muda menurut jalan yang patut baginya , maka pada masa tuanyapun ia tidak akan menyimpang dari pada jalan itu." Untuk itu, kajian ini menghadirkan fakta-fakta yang valid dan aktual tentang kurikulum pendidikan karakter dan relevansinya bagi Pendidikan Agama Kisten pada masa sekarang ini.

Jika kita melihat dan melompat jauh ke tahun 2045, pada se-abad Indonesia merdeka, pemerintah memiliki visi yang jelas untuk Indonesia ke depan. Tahun itu digadang-gadang akan menjadi moment kebangkitan Indonesia dalam berbagai bidang. Pemerintah dengan Visi Indonesia emas tahun 2045 menargetkan untuk duduk sebagai 7 besar negara berkekuatan ekonomi hebat di dunia. Dengan tercapainya visi ini Indonesia akan menjadi negara yang kuat dan maju. Dalam visi itu juga dijelaskan bahwa bangsa Indonesia akan menjadi negara yang adil dan makmur, sehingga rakyat akan tersejahterakan dan merasakan keadilan sosial yang merata di setiap wilayah NKRI tercinta ini.

Di kala itu terwujud, maka Indonesia akan bersaing dengan negara-negara besar yang hebat lainnya. Indonesia yang terletak di wilayah garis khatulistiwa adalah sebuah negara kepulauan yang sangat besar dan luas dengan populasi penduduk 265.000.000 jiwa yang terdiri dari 133,17 juta jiwa laki-laki dan 131,88 juta jiwa perempuan. ${ }^{3}$ Menurut data Badan Pusat Statistik (BPS) tahun 2016 jumlah pulau di Indonesia adalah 17.504 pulau. ${ }^{4}$ Pulau-pulau tersebut dihuni oleh lebih dari 300 kelompok etnik dan 1.340 suku bangsa menurut data resmi dari yang dikeluarkan pada tahun 2010 oleh BPS. ${ }^{5}$

Dari gambaran statistik tersebut, kita dapat membayangkan betapa kayanya negeri ini akan adat istiadat, budaya dan bahasa. Jika semua itu di jaga dan dilestarikan dengan baik maka ada potensi kearifan lokal yang dapat membentuk karakter anak bangsa sesuai dengan konteks kearifan lokal tersebut, sehingga kita bisa melihat anak-anak Indonesia ke depan adalah anak-anak yang memahami Indonesia sesuai dengan konteks daerah-daerah kepulauan tersebut dan dijaga dalam kesatuan Bhineka Tunggal Ika.

\footnotetext{
${ }^{1}$ Agus Wibowo, Pendidikan Karakter: Strategi Membangun Karakter Bangsa Berperadaban, (Yogyakarta: Pustaka Pelajar, 2012), 1.

${ }^{2}$ Nana Syaodih Sukmadinata, Kurikulum \& Pembelajaran Kompetensi,Yayasan, (Bandung: Kusuma Karya, 2004), 151.

${ }^{3}$ Diakses pada 8 Januari 2019. https://databoks.katadata.co.id/datapublish/2018/05/18/2018-jumlahpenduduk-indonesia-mencapai-265-juta-jiwa

${ }^{4}$ Diakses pada 8 januari 2019. https://www.bps.go.id/statictable/2014/09/05/1366/luas-daerah-danjumlah-pulau-menurut-provinsi-2002-2016.html

${ }^{5}$ Diakses pada 8 Januari 2019.

http://www.netralnews.com/news/rsn/read/71459/di.indonesia.ada.1340.suku.bangsa.dan.300.kelompok.etnik
} 
Memang belakangan ini banyak terlihat, ada segelintir anak muda yang memiliki pola hidup budaya barat yang tidak cocok apabila di pakai dalam konteks ke Indonesiaan kita. Budaya-budaya barat itu mau tidak mau menggerus pemahaman anak muda akan akar budaya dan adat-istiadat ketimuran bangsa ini, tapi bukan berarti semua yang datang dari barat tidak baik dan kita tolak. Hal-hal yang baik dan positif kita terima sedangkan hal-hal yang negatif kita buang dan tidak dipakai, agar anak-anak muda sebagai generasi bangsa tidak kehilangan identitas ke-indonesiaannya.

Kita juga melihat bahwa banyak pemimpin-pemimpin kita yang terlibat korupsi yang mengakibatkan kerugian negara begitu besar. Hal itu begitu menyakitkan, karena banyak masyarakat yang dikorbankan akibat perbuatan korupsi para pejabat ini. Korupsi membuat masyarakat miskin dan pembangunan tidak merata, karena korupsi hanya memperkaya para koruptor serta kelompok-kelompoknya dan menghancurkan sendi-sendi kehidupan masyarakat.

Hal lainnya yang menjadi sorotan adalah rasa saling menghormati, menghargai dan bergotong royong tampaknya mulai terkikis, sehingga seringkali konflik antar golongan pun terjadi. Indonesia yang dulu begitu indah di rusak oleh orang-orang yang tidak memahami Indonesia dengan utuh, perang antar suku menghancurkan harmoni kita sehingga kebhinekaan kita tercederai, bahkan tak sedikit pula konflik-konflik ke agamaanpun mewarnai kericuhan negeri ini, sungguh menyayat hati dan menyedihkan melihat semua ini terjadi di negeri tercinta ini.

Untuk itu, agar cita-cita pemerintah dalam Visi Indonesia emas tahun 2045 tercapai, maka perlu untuk melakukan pembenahan dalam bidang pendidikan, sehingga para generasi penerus bangsa memiliki karakter yang kuat, tangguh dan kokoh yang mengakibatkan mereka siap memimpin negeri ini ke depan dan siap pula bersaing dengan bangsa lain. Oleh sebab itu kita memerlukan penguatan pendidikan karakter bagai anakanak negeri.

\section{Pentingnya Kurikulum Berbasis Penguatan Pendidikan Karakter}

Penguatan Pendidikan Karakter atau (PPK) adalah program pendidikan di sekolah untuk memperkuat karakter siswa melalui harmonisasi olah hati (etik dan spiritual), olah rasa (estetik), olah pikir (literasi dan numerasi) dan olah raga (kinestetik) sesuai dengan falsafah Pancasila. ${ }^{6}$ Penguatan Pendidikan Karakter dapat dilakukan di sekolah dan lingkungan sosial masyarakat lainnya. Tujuan dari PPK tersebut harusnya difokuskan untuk menanamkan nilai-nilai pancasila dan rasa nasionalisme di jiwa masing-masing anak Indonesia sehingga melalui PPK terlahirlah anak-anak generasi emas menuju Indonesia jaya yang berkemajuan dan berdaya saing global.

Tak dapat dipungkiri bahwa kurikulum merupakan salah satu faktor utama bagi keberhasilan pendidikan negeri ini, untuk itu hendaknya kurikulum berbasis pendidikan karakter harus di desain sedemikian rupa agar dapat terlihat jelas hasilnya. Menurut Nana

${ }^{6}$ Diakses pada 7 Januari 2019. https://cerdasberkarakter.kemdikbud.go.id/ 
Saodih Sukmadinata, kurikulum merupakan rancangan pendidikan yang merangkum semua pengalaman belajar yang disediakan bagi siswa di sekolah. ${ }^{7}$

Pengembangan kurikulum adalah sebuah proses yang merencanakan, menghasilkan suatu alat yang lebih baik dengan didasarkan pada hasil penilaian terhadap kurikulum yang telah berlaku,sehingga dapat memberikan kondisi belajar mengajar yang baik. Dengan kata lain pengembangan kurikulum adalah kegiatan untuk menghasilkan kurikulum baru melalui langkah-langkah penyusunan kurikulum atas dasar hasil penilaian yang dilakukan selama periode waktu tertentu. ${ }^{8}$ Pada umumnya ahli kurikulum memandang kegiatan pengembangan kurikulum sebagai suatu proses yang kontinue, merupakan suatu siklus yang menyangkut beberapa kurikulum yaitu komponen tujuan, bahan, kegiatan dan evaluasi. ${ }^{9}$

Selanjutnya Sukmadinata ${ }^{10}$ menjelaskan bahwa dalam memahami konsep kurikulum, setidaknya ada tiga pengertian yang harus dipahami, yaitu:

1. Kurikulum sebagai substansi atau sebagai suatu rencana belajar.

2. Kurikulum sebagai suatu sistem, yaitu sistem kurikulum yang merupakan bagian dari sistem persekolahan dan sistem pendidikan, bahkan sistem masyarakat.

3. Kurikulum sebagai suatu bidang studi, yaitu bidang kajian kurikulum,yang merupakan bidang kajian para ahli kurikulum, pendidikan dan pengajaran.

Sementara Oemar Hamalik ${ }^{11}$ membagi prinsip pengembangan kurikulum menjadi delapan macam, antara lain:

1. Prinsip Berorientasi Pada Tujuan. Pengembngan kurikulum diarahkan untuk mencapai tujuan tertentu, yang bertitik tolak dari tujuan pendidikan Nasional. Tujuan kurikulum merupakan penjabaran dan upaya untuk mencapai tujuan satuan dan jenjang pendidikan tertentu. Tujuan kurikulum mengadung aspekaspek pengetahuan, ketrampilan, sikap dan nilai, yang selanjutnya menumbuhkan perubahan tingkah laku peserta didik yang mencakup tiga aspek tersebut dan bertalian dengan aspek-aspek yang terkandung dalam tujuan pendidikan nasional.

2. Prinsip Relevansi (Kesesuaian). Pengembangan kurikulum yang meliputi tujuan, isi dan system penyampaian harus relevan (sesuai) dengan kebutuhan dan keadaan masyarakat, tingkat perkembangan dan kebutuhan siswa, serta serasi dengan perkembangan ilmu pengetahuan dan tegnologi.

3. Prinsip Efisiensi dan Efektifitas. Pengembangan kurikulum harus mempertimbangkan segi efisien dan pendayagunaan dana, waktu, tenaga, dan

\footnotetext{
${ }^{7}$ Nana Syaodih Sukmadinata, Kurikulum \& Pembelajaran Kompetensi, (Bandung : Yayasan Kusuma Karya, 2004), 150.

${ }^{8}$ Nur Ahid, Makalah Pengembangan Kurikulum Pendidikan Karakter (Jakarta: Institut Agama Islam Tribakti, 2013), 5

${ }^{9}$ Nur Ahid, Makalah Pengembangan Kurikulum Pendidikan Karakter, 6

${ }^{10}$ Sukmadinata, Kurikulum \& Pembelajaran Kompetensi, 151.

${ }^{11}$ Oemar Hamalik, Proses belajar Mengajar . (Bandung : Bumi Aksara, 2001) ,99-105.
} 
sumber-sumber yang tersedia agar dapat mencapai hasil yang optimal. Dana yang terbatas harus digunakan sedemikian rupa dalam rangka mendukung pelaksanaan pembelajaran.Waktu yang tersedia bagi siswa belajar disekolah juga terbatas sehingga harus dimanfaatkan secara tepat sesuai dengan tata ajarandan bahan pembelajaran yang diperlukan. Tenaga disekolah jugasangat terbatas, baik dalam jumlah maupun dalam mutunya, hendaknya didaya gunakan secara efisien untuk melaksanakan proses pembelajaran. Demikian juga keterbatasan fasilitas ruangan, peralatan,dan sumber kerterbacaan, harus digunakan secara tepat oleh sswadalam rangka pembelajaran, yang semuanya demi meningkatkanefektifitas atau keberhasilan siswa.

4. Prinsip Fleksibilitas. Kurikulum yang luwes mudah disesuaikan, diubah, dilengkapi atau dikurangi berdasarkan tuntutan dan keadaan ekosistem dan kemampuan setempat, jadi tidak statis atau kaku. Misalnya dalam suatu kurikulum disediakan program pendidikan ketrampilan industridan pertanian. Pelaksanaaan di kota, karena tidak tersedianya lahan pertanian., maka yang dialaksanakan program ketrampilan pendidikn industri. Sebaliknya, pelaksanaan di desa ditekankan pada program ketrampilan pertanian. Dalam hal ini lingkungan sekitar, keadaaan masyarakat, dan ketersediaan tenaga dan peralatan menjadi faktor pertimbangan dalam rangka pelaksanaan kurikulum.

5. Prinsip Kontiunitas. Kurikulum disusun secara berkesinambungan, artinya bagian-bagian, aspek-spek, materi, dan bahan kajian disusun secara berurutan, tidak terlepas-lepas, melainkan satu sama lain memilik hubungan fungsional yang bermakna, sesuai dengan jenjang pendidikan, struktur dalamsatuan pendidikn, tingkat perkembangan siswa. Dengan prinsip ini,tampak jelas alur dan keterkaitan didalam kurikulum tersebut sehinggamempermudah guru dan siswa dalam melaksanakan proses pembelajaran.

6. Prinsip Keseimbangan. Penyusunan kurikulum memerhatikan keseimbangan secara proposional dan fungsional antara berbagai program dan subprogram,antara semau mata ajaran, dan antara aspek-aspek perilaku yang ingindikembangkan. Keseimbangan juga perlu diadakan antara teori dan praktik, antara unsur-unsur keilmuan sains, sosial, humaniora, dankeilmuan perilaku. Dengan keseimbangan tersebut diaharapkanterjalin perpaduan yang lengkap dan menyeluruh, yang satu samalainnya saling memberikan sumbangan terhadap pengembangan pribadi.

7. Prinsip Keterpaduan. Kurikulum dirancang dan dilaksanakan berdasarkan prinsip keterpaduan, perencanaan terpadu bertitik tolak dari masalah atautopik dan konsistensi antara unsur-unsusrnya. Pelaksanaan terpadu dengan melibatkan semua pihak, baik di lingkungan sekolah maupun pada tingkat inter sektoral. Dengan keterpaduan ini diharapkan terbentuk pribadi yang bulat dan utuh. 
Diamping itu juga dilaksanakan keterpaduan dalam proses pembalajaran, baik dalam interaksi antar siswa dan guru maupun antara teori dan praktek.

8. Prinsip Mutu. Pengembangan kurikulum berorientasi pada pendidikan mutu, yang berarti bahwa pelaksanaan pembelajaran yang bermutu ditentukan oleh derajat mutu guru, kegiatan belajar mengajar, peralatan, media yang bermutu. Hasil pendidikan yang bermutu diukur berdasarkan kriteria tujuan pendidikan nasional yang diaharapkan.

Sebagaimana yang dijelaskan oleh Sukmadinata dan Hamalik di atas penulis setuju bahwa hendaknya kurikulum yang berbasis PPK haruslah juga memperhatikan etika ketimuran bangsa Indonesia, agar anak-anak bangsa negeri ini tetap hidup dalam kesopansantunan para leluhur dan mampu menyaring budaya asing, sehingga tidak menggerus keluhuran budaya asli negeri tercinta. Untuk mencetak anak-anak bangsa yang seperti itu perlu penekanan yang kuat dalam kurikulum yang diterapkan di sekolah-sekolah, yang di dalamnya juga memasukkan 5 (lima) nilai utama pendidikan karakter Indonesia yang bersumber dari Pancasila dan yang merupakan prioritas gerakan PPL, yakni: Religius, Nasionalis, Mandiri, Integritas, Gotong Royong. Masing-masing nilai tidak berdiri dan berkembang sendiri-sendiri, melainkan saling berinteraksi satu sama lain, berkembang secara dinamis dan membentuk keutuhan pribadi. ${ }^{12}$

Penjabaran untuk ke lima (5) nilai utama pendidikan karakter Indonesia itu, meliputi: ${ }^{13}$

1. Nilai karakter religius mencerminkan keberimanan terhadap Tuhan yang Maha Esa yang diwujudkan dalam perilaku melaksanakan ajaran agama dan kepercayaan yang dianut, menghargai perbedaan agama, menjunjung tinggi sikap toleran terhadap pelaksanaan ibadah agama dan kepercayaan lain, hidup rukun dan damai dengan pemeluk agama lain. Implementasi nilai karakter religius ini ditunjukkan dalam sikap cinta damai, toleransi, menghargai perbedaan agama dan kepercayaan, teguh pendirian, percaya diri, kerja sama antar pemeluk agama dan kepercayaan, anti perundungan dan kekerasan, persahabatan, ketulusan, tidak memaksakan kehendak, mencintai lingkungan, melindungi yang kecil dan tersisih.

2. Nilai karakter nasionalis merupakan cara berpikir, bersikap, dan berbuat yang menunjukkan kesetiaan, kepedulian, dan penghargaan yang tinggi terhadap bahasa, lingkungan fisik, sosial, budaya, ekonomi, dan politik bangsa, menempatkan kepentingan bangsa dan negara di atas kepentingan diri dan kelompoknya. Sikap nasionalis ditunjukkan melalui sikap apresiasi budaya bangsa sendiri, menjaga kekayaan budaya bangsa, rela berkorban, unggul, dan berprestasi, cinta tanah air, menjaga lingkungan, taat hukum, disiplin, menghormati keragaman budaya, suku, dan agama.

\footnotetext{
${ }^{12}$ Diakses pada 7 Januari 2019. https://www.kemdikbud.go.id/main/blog/2017/07/penguatanpendidikan-karakter-jadi-pintu-masuk-pembenahan-pendidikan-nasional.

${ }^{13}$ Ibid 
3. Nilai karakter integritas merupakan nilai yang mendasari perilaku yang didasarkan pada upaya menjadikan dirinya sebagai orang yang selalu dapat dipercaya dalam perkataan, tindakan, dan pekerjaan, memiliki komitmen dan kesetiaan pada nilainilai kemanusiaan dan moral. Karakter integritas meliputi sikap tanggung jawab sebagai warga negara, aktif terlibat dalam kehidupan sosial, melalui konsistensi tindakan dan perkataan yang berdasarkan kebenaran. Seseorang yang berintegritas juga menghargai martabat individu (terutama penyandang disabilitas), serta mampu menunjukkan keteladanan.

4. Nilai karakter mandiri merupakan sikap dan perilaku tidak bergantung pada orang lain dan mempergunakan segala tenaga, pikiran, waktu untuk merealisasikan harapan, mimpi dan cita-cita. Siswa yang mandiri memiliki etos kerja yang baik, tangguh, berdaya juang, profesional, kreatif, keberanian, dan menjadi pembelajar sepanjang hayat.

5. Nilai karakter gotong-royong mencerminkan tindakan menghargai semangat kerja sama dan bahu membahu menyelesaikan persoalan bersama, menjalin komunikasi dan persahabatan, memberi bantuan/pertolongan pada orang-orang yang membutuhkan. Diharapkan siswa dapat menunjukkan sikap menghargai sesama, dapat bekerja sama, inklusif, mampu berkomitmen atas keputusan bersama, musyawarah mufakat, tolong menolong, memiliki empati dan rasa solidaritas, anti diskriminasi, anti kekerasan, dan sikap kerelawanan.

Penguatan kurikulum yang berbasiskan pendidikan karakter ini membutuhkan sinergitas yang kuat di antara pemerintah (pusat/daerah), masyarakat, sekolah, orang tua serta perangkat pendukung lainnya, agar apa yang diharapkan oleh pemerintah kita untuk mencetak generasi emas pada tahun 2045 dapat terwujud dan tercapai secara utuh. Generasi-generasi muda tersebut adalah generasi-generasi muda yang di cetak untuk memiliki kemampuan dan kecakapan yang mumpuni dan juga memiliki kemampuan daya saing global di abad 21 ini.

\section{Diskusi}

\section{Generasi Emas Indonesia dalam Bingkai Visi Indonesia Tahun 2045}

Cita-cita luhur bangsa ini untuk menjadi negara yang kuat, maju dan sejahtera serta berkeadilan bukanlah sebuah impian belaka, semua itu dapat terwujud, itu sebab negara harus berupaya dengan sekuat tenaga mencerdaskan kehidupan bangsa sesuai dengan amanat dalam Pembukaan UUD 1945 (Preambule). Negara harus bisa mencetak generasi bangsa yang unggul, generasi emas yang akan membawa negeri tercinta ini kepada puncak-puncak kejayaaannya kembali seperti yang pernah terjadi di zaman kerajaan Sriwijaya dan Majapahit. Pemerintah harus melibatkan semua element masyarakat untuk mendukung proyek generasi emas di tahun 2045 ini, termasuk di dalamnya adalah pemudapemudi Indonesia, seperti yang terjadi di jakarta dalam konfrensi Pemuda-Pemudi Indonesia (PPI) sedunia di Jakarta, pada tanggal 13-15 Agustus 2018. 
Dalam kesempatan itu, seminggu setelah berlangsung Conference of Indonesian Diaspora Youth 2018 (CIDY-2018) tanggal 13 - 15 Agustus 2018 di Hotel Grand Sahid Jaya, Jakarta. PPI Dunia mendapat apresiasi dan kehormatan untuk mengemban amanat membentuk Pemuda Indonesia yang mampu berkontribusi aktif atas intelektual dan kompetesinya membangun Indonesia kedepan dengan tema "Merancang Visi Indonesia 2045". Konvensi ini mempertemukan pemuda cemerlang dari 34 Provinsi Indonesia dengan diaspora muda Indonesia dari seluruh dunia, serta dengan berbagai organisasi kepemudaan dan juga lembaga nasional.

CIDY-2018 ini telah menghadirkan 15 sesi menarik untuk membahas berbagai topik yang aktual bagi pemuda dan bagi masa depan Indonesia. Sesi-sesi tersebut dilaksanakan secara paralel. Semua peserta utusan dan delegasi berhak berbicara sesuai peraturan dan waktu yang tersedia. Semua sesi dirancang untuk memberi ruang bagi para pemuda untuk berdiskusi secara aktif dan dinamis, dan bukan lah ajang mendengarkan ceramah secara pasif dari generasi sebelumnya. Dalam penyelenggaraan CIDY-2018, Indonesian Diaspora Network Global (IDN-Global)selain dengan bangga berkolaborasi dengan Perhimpunan Pelajar Indonesia se-Dunia (PPI Dunia), juga berkolaborasi dengan Foreign Policy Community of Indonesia (FPCI), Asosiasi Dosen Indonesia (ADI), dan Forum Rektor Indonesia. Konferensi ini juga didukung oleh Kementerian Luar Negeri Indonesia, Kementerian Pemuda dan Olahraga Indonesia, Kementerian Riset, Teknologi, dan Pendidikan Tinggi Indonesia, serta Pemerintah Provinsi DKI Jakarta.

Konvensi ini sebagai suatu ajang membangun bangsa yang menjadi bagian dari perjalanan negara. Sebagaimana diketahui, pada tanggal 27-28 Oktober 1928, ratusan pemuda dari berbagai daerah di Nusantara berkumpul di kota Batavia (sekarang Jakarta) dan merumuskan 3 visi mengenai masa depan bangsa yang masih terjajah. Visi Sumpah Pemuda inilah yang kemudian menjiwai perjalanan bangsa melalui abad ke-20. Ketiga visi tersebut - Satu Tanah Air, Satu Bangsa, Satu Bahasa - telah tercapai. Kini, di abad ke21, generasi muda tertantang untuk memikirkan Visi Indonesia ke depan yang dapat menjadi bahan acuan bangsa, sebagaimana Sumpah Pemuda pada tahun 1928 menjadi acuan bagi generasi-generasi berikutnya. Misi inilah yang dicoba untuk dirumuskan oleh "Proyek Visi 2045: Satu Abad Republik Indonesia. ${ }^{14}$

Berikut pesan utama yang harus dibaca oleh seluruh pemuda Indonesia demi membangun Indonesia 2045 sebagai berikut: "Kami, pemuda Indonesia dari 34 provinsi dan komunitas diaspora, berkumpul di Indonesia pada tanggal 13 - 15 Agustus guna merumuskan aspirasi untuk 1 Abad Republik Indonesia — Visi Indonesia 2045. Kami menegaskan komitmen sejarah terhadap Pancasila, UUD 1945, Bhinneka Tunggal Ika, dan Negara Kesatuan Republik Indonesia guna berpegang teguh pada pilar-pilar kebangsaan

\footnotetext{
${ }^{14}$ Diakses pada 9 Januari 2019. http://ppidunia.org/2018/08/27/pesan-untuk-pemuda-indonesia-gagasvisi-indonesia-2045-bersama-diaspora/
} 
tersebut. Kami bertekad untuk melanjutkan semangat Sumpah Pemuda 1928 dengan Visi Indonesia 2045 guna membawa bangsa kita ke zaman emas. ${ }^{15}$

\section{Kondisi Dunia 2045}

Sebagaimana Republik Indonesia lahir dari reruntuhan Perang Dunia II, perjalanan 100 tahun NKRI akan selalu dipengaruhi kondisi global. Di abad ke-21, bangsa kita akan mengalami kenaikan suhu bumi antara 2-3 derajat Celsius, dengan segala konsekuensi seriusnya bagi planet dan keselamatan umat manusia. Indonesia akan terus menghadapi lingkungan geopolitik yang multipolar, dan Asia akan menjadi pusat ekonomi dunia dengan kelas menengah terbesar yang terus berkembang pesat. Di pertengahan abad ini, ekonomi dunia akan menjadi dua kali lebih besar dibanding sekarang dan pertumbuhannya akan lebih cepat bila dibandingkan dengan populasi dunia yang diperkirakan akan mencapai 9,8 miliar jiwa di tahun 2045. Shared Economy akan menjadi lebih umum, demikian pula masyarakat tanpa mata uang fisik terlebih karena modernisasi, termasuk konektivitas semakin menjalar ke berbagai negara berkembang.

Dengan segala peluang ini, bangsa Indonesia harus terus mewaspadai berbagai risiko: kita perlu mengantisipasi timbulnya sejumlah krisis finansial dan ekonomi dalam tiga dekade mendatang di mana ketimpangan (inequity) akan terus menjadi tren dunia, dan kita perlu mengantisipasi persaingan geostrategis yang diwarnai pembangunan militer dan militerisasi wilayah konflik yang akan terus bergulir, kita juga perlu mengantisipasi meletusnya perang besar di kancah internasional melihat radikalisme, ekstremisme, dan terorisme yang akan terus menghantui dunia, belum lagi ancaman pandemi dan endemi penyakit menular.

\section{Posisi Indonesia Saat Ini ${ }^{16}$ dan Proyeksi pada 2045}

Bangsa kita telah melangkah jauh sejak Republik Indonesia lahir di tanggal 17 Agustus 1945. Kami bangga bahwa Indonesia telah menjadi negara demokrasi terbesar ketiga di dunia. Indonesia telah tumbuh menjadi ekonomi nomor 16 terbesar dunia dan ekonomi terbesar, dengan kelas menengah dan pasar terbesar di Asia Tenggara. Indonesia juga telah memiliki posisi strategis di percaturan global sebagai negara anggota KTT G-20. Kita telah berhasil mencapai angka 100\% untuk akses akan pendidikan dasar, angka 98\% tingkat literasi orang dewasa, angka usia harapan hidup 71 tahun untuk rakyat, serta mencapai angka tingkat kemiskinan absolut terendah dalam sejarah Indonesia.

Di tahun 2045, jumlah penduduk Indonesia diperkirakan mencapai 321 juta orang, dengan penduduk berusia produktif sekitar 209 juta, maka dari itu Indonesia diproyeksikan menjadi ekonomi $\$ 9$ triliun dan secara otomatis masuk ke dalam lima besar ekonomi dunia. Lebih dari $70 \%$ penduduk Indonesia akan tinggal di wilayah perkotaan mengingat

\footnotetext{
${ }^{15}$ Ibid

${ }^{16}$ Diakses pada 9 Januari 2019. http://ppidunia.org/2018/08/27/pesan-untuk-pemuda-indonesia-gagasvisi-indonesia-2045-bersama-diaspora/
} 
pusat-pusat pertumbuhan daerah akan berlipat-ganda, terlebih karena pembangunan infrastruktur yang semakin merata.

Pembangunan Indonesia harus terus beradaptasi dengan perkembangan zaman dan perubahan kondisi rakyat. Pembangunan kita harus semakin mengedepankan etika dan berkepedulian terhadap kelompok-kelompok yang termarginalisasi, termasuk kelompok difabel. Di abad ke-21 ini, Indonesia harus melaksanakan pembangunannya dengan mengedepankan identitas dan keindonesiaan bangsa kita. Oleh karena itu, kami bertekad untuk melestarikan budaya dan bahasa lokal agar tidak ada yang punah.

Mengantisipasi semakin maraknya perkembangan artificial intelligence dan automasi, kita harus terus menjaga agar manusia Indonesia tetap menjadi pelaksana utama dalam strategi pembangunan kita ke depan. Kita juga harus menjamin agar pembangunan yang kita jalankan tidak saja dapat memberikan kemakmuran secara materil, namun juga dapat memberikan kesejahteraan bagi manusia Indonesia. Pembangunan kita tidak cukup hanya menekankan aspek kesetaraan (equality), tapi juga pada persamaan peluang (equal opportunity). Pembangunan Indonesia ke depan juga harus semakin berbasis kearifan lokal dan memenuhi kebutuhan daerah sehingga dapat menciptakan pusat-pusat pertumbuhan ekonomi baru yang mampu menjembatani disparitas regional yang selama ini masih mewarnai ekonomi Indonesia.

\section{Visi Indonesia $2045^{17}$}

Menuju seratus tahun lahirnya Republik Indonesia, bangsa Indonesia harus terus memacu perubahan dan kemajuan di berbagai sektor. Kami menginginkan demokrasi Indonesia yang berkualitas, didukung sistem pemilihan umum yang fair dan berintegritas, yang bisa menghasilkan pemimpin-pemimpin yang bersih, akuntabel, dan berbobot, yang berorientasi pada rakyat dan dapat membawa kebaikan dan perbaikan bagi bangsa dan negara. Perjalanan demokrasi Indonesia ke depan harus memperkokoh perlindungan dan pemenuhan hak manusia di Indonesia dan juga di kancah internasional.

Kami juga ingin agar generasi 2045 nanti dapat menikmati supremasi hukum secara murni, konsisten, dan absolut yang diterapkan di seluruh wilayah NKRI tanpa pandang bulu, bebas politik, dan bebas kepentingan. Untuk itu, reformasi hukum, guna memberikan hukum yang progresif dan berkeadilan bagi rakyat Indonesia harus terus ditempatkan sebagai agenda utama perjalangan bangsa dalam tiga dekade ke depan. Dalam satu generasi ke depan, kami memandang bahwa ini merupakan salah satu perubahan paling strategis yang harus dicapai.

Kami mendambakan pemerintah nasional dan daerah yang bersih, responsif, kompeten, dan meritokratis. Kami juga ingin putra-putri terbaik Indonesia untuk masuk ke dalam pemerintahan dan birokrasi Indonesia untuk ikut memastikan percepatan reformasi.

\footnotetext{
${ }^{17}$ Diakses pada 9 Januari 2019. http://ppidunia.org/2018/08/27/pesan-untuk-pemuda-indonesia-gagasvisi-indonesia-2045-bersama-diaspora/
} 
Menuju usianya yang 100 tahun, kami ingin Indonesia di abad ke-21 menjadi bangsa kelas menengah yang tulen dengan kualitas hidup tinggi dan beretos meritokrasi.

Kami ingin agar sumber daya manusia menjadi aset pembangunan bangsa terbesar. Untuk itu, kami mendambakan emansipasi pendidikan bagi seluruh rakyat Indonesia, di mana setiap warga negara di manapun, mempunyai peluang untuk mengakses pendidikan berkualitas terlepas dari kondisi ekonominya. Sistem pendidikan Indonesia (kurikulum, sumber daya pengajar, infrastruktur) juga harus menghasilkan manusia Indonesia yang berpikir kritis, kreatif, inovatif, dan berdaya saing global. Kami ingin melihat pendidikan yang semakin disesuaikan dengan potensi kedaerahan dan memperkuat budaya daerah.

Pembangunan dan pendidikan Indonesia harus berbasis riset. Investasi untuk riset di Indonesia, baik oleh pemerintah maupun swasta harus ditingkatkan menjadi 3\% per GDP. Indonesia juga harus menjadi negara termudah di Asia untuk mendapatkan paten. Mengingat era digital akan terus berkembang, kami ingin agar setiap manusia Indonesia, di manapun, memiliki literasi digital (digital literacy), termasuk dalam pelayanan gerejawi. ${ }^{18}$ Kami juga ingin agar konektivitas digital diperlakukan sebagai bagian dari hak manusia (human rights).

Kami memiliki visi agar seluruh lapisan masyarakat dapat mengakses pelayanan kesehatan yang berkualitas terlepas dari kondisi ekonomi dan geografis. Kami juga ingin agar sistem pelayanan kesehatan nasional dapat memperluas distribusi personalized medicine kepada rakyat Indonesia, dan kami berkeinginan agar semua anak Indonesia mendapatkan akses vaksin, baik preventif maupun kuratif, untuk melawan penyakit degeneratif dan menular.

Kami beraspirasi agar bangsa Indonesia di tahun 2045 menjadi bangsa entrepreneur. Entrepreneur kita harus menjadi pelopor anti-korupsi yang mampu memberikan manfaat sosial dan memiliki kesadaran lingkungan.

Kami ingin Indonesia dapat menjadi ekonomi yang unggul dalam Revolusi Industri 4.0 dan seterusnya, serta menjadi bangsa pemenang globalisasi. Di usianya yang satu abad nanti, kami ingin melihat Indonesia menjadi kekuatan maritim dunia. Guna mencapainya, Indonesia harus mempunyai kapasitas militer untuk menjaga kedaulatan dan melindungi kepentingan nasional di wilayah maritim NKRI, terlebih dengan dibangunnya Blue Water Navy yang dapat membantu menjaga stabilitas keamanan kawasan. Industri pertahanan maritim Indonesia juga harus mampu menjadi yang terdepan di Asia.

Mengingat meningkatnya ancaman siber global, kami ingin Indonesia memiliki kemampuan pertahanan siber yang tangguh di tahun 2045. Menjelang usia Republik Indonesia yang satu abad, kami beraspirasi agar sejumlah masalah-masalah bangsa hari ini bisa dilenyapkan di tahun 2045 atau sebelumnya.

\footnotetext{
${ }^{18}$ Harls Evan R. Siahaan, “Aktualisasi Pelayanan Karunia Di Era Digital,” EPIGRAPHE: Jurnal Teologi dan Pelayanan Kristiani 1, no. 1 (2017): 23-38, www.stttorsina.ac.id/jurnal/index.php/epigraphe.
} 
Kami ingin agar generasi 2045 menjadi generasi pertama dalam sejarah Republik Indonesia yang tidak lagi dibebani oleh separatisme.

Kami juga ingin melihat kemiskinan absolut terhapus dari bumi Indonesia dan kami ingin agar upaya pengentasan kemiskinan dapat bergeser dengan menargetkan perubahan nasib 60\% masyarakat Indonesia yang berada di bawah garis kemiskinan. Di tahun 2045, kami ingin tidak ada lagi anak Indonesia yang mengalami stunting, tidak ada lagi kerja paksa anak dan perbudakan modern, tidak ada lagi perkawinan usia anak, tidak ada lagi buta huruf, tidak ada lagi kelaparan dan kurang gizi, tidak ada lagi desa tertinggal, tidak ada lagi sengketa batas wilayah negara yang belum terselesaikan, tidak ada lagi deforestasi, dan tidak ada lagi pungutan liar di wilayah Indonesia.

Walaupun kami menyadari beratnya tantangan-tantangan ini, kami percaya bahwa dengan upaya sistemik yang sungguh-sungguh dan konsisten, pemerintah Indonesia akan menjadi relatif bebas korupsi dalam satu generasi ke depan. Semua visi ini membutuhkan internasionalisme Indonesia yang sepadan. Maka dari itu, kami ingin melihat politik luar negeri bebas-aktif diimplementasikan secara maksimal, agar dapat menjadikan Indonesia Major Power Asia dan pelopor global. Kami beraspirasi agar Indonesia terus menjadi jangkar Asia Tenggara, pemimpin ASEAN, serta pendekar multilateralisme.

Indonesia tidak boleh ditakuti, tetapi dihormati dan diteladani dunia. Kami juga mencita-citakan masuknya Indonesia ke dalam lima besar kekuatan perdagangan dunia, sejalan dengan kekuatan ekonomi kita pada waktunya.

Sebagai Penutup dari konfrensi itu para pemuda Indonesia juga memiliki keyakinan, yakni:

Kami, pemuda Indonesia, meyakini bahwa bangsa Indonesia ditakdirkan menjadi bangsa besar dunia. Kami juga meyakini abad ke-21 akan menjadi abad kejayaan Indonesia. Naskah ini diharapkan menjadi acuan sejarah bagi perjalanan bangsa Indonesia guna menginspirasi pemimpin dan rakyat Indonesia ke depan. Oleh karena itu, kami mengajak seluruh rakyat Indonesia untuk mendukung, menyebarkan, dan mewujudkan visi yang mulia ini. Kami yakin visi dan aspirasi yang kami torehkan ini adalah acuan ambisius yang layak dimiliki rakyat Indonesia. Maka dari itu, kami persembahkan dokumen ini bagi Hari Kemerdekaan Republik Indonesia ke-73. Atas berkat Rahmat Tuhan yang Maha Esa dan atas nama pemuda Indonesia. Jakarta, 15 Agustus 2018. ${ }^{19}$

Dari konferensi itu penulis melihat jelas bahwa ada keinginan kuat dari para Pemuda Indoensia untuk terlibat aktif memajukan bangsanya, sehingga negeri ini benar-benar berdiri kokoh menjadi negeri yang maju dan memiliki karakter ke Indonesiaan yang berarkar kuat dari budaya Indonesia itu sendiri.

\footnotetext{
${ }^{19}$ Diakses pada 9 Januari 2019. http://ppidunia.org/2018/08/27/pesan-untuk-pemuda-indonesia-gagasvisi-indonesia-2045-bersama-diaspora/
} 


\section{Relevansinya Bagi Pendidikan Agama Kristen Masa Kini}

Pendidikan Agama Kristen merupakan pendidikan yang bercorakkan moral-moral kristiani, maksudnya materi pengajaran Pendidikan Agama Kristen merupakan materi yang berisi tentang nilai-nilai kebenaran iman Kristen. ${ }^{20}$ Nico Syukur Dister menegaskan pendapatnya bahwa "Pendidikan Kristen harus yang bercorak, berdasarkan dan berorientasi kepada iman Kristiani."21 Atau dengan kata lain bahwa semua bentuk aktivitas proses belajar mengajar yang terjadi didalam dan diluar kelas terwujud dalam ruang lingkup di sekolah, gereja atau lingkungan keluarga didasarai oleh pengajaran iman Kristen.

Dalam proses pembelajaran Pendidikan Agama Kristen, seorang nara didik selain memberikan pengajaran yang bersifat pemahaman ajaran-ajaran iman Kristen juga bertanggung jawab memberikan sikap keteladanan tingkah laku, keyakinan, nilai-nilai, sikap-sikap dan ketrampilan yang sesuai dengan iman Kristen. Boediono mengatakan bahwa "Model kurikulum Pendidikan Agama Kristen (Pendidikan Agama Kristen) didominasi oleh doktrin agama yang lebih mengutamakanaspek kognitif dan cenderung melupakan hal pokok dan utama dalam Pendidikan Agama, yaitu: pemahaman terhadap nilai-nilai agama yang bersentuhan dengan realitas kehidupan nyata." ${ }^{22}$

Maksud dari pernyataan Boediono itu adalah bahwa dalam pembelajaran Pendidikan Agama Kristen para peserta didik dibekali dengan pengetahuan (kognitif) agar mengetahui tangungjawab pribadi dalam meningkatkan kualitas kehidupan yang berarti bagi bangsa dan negaranya, masyarakat luas dan gerejanya serta keluarga sebagai cerminan kehidupan Kristen. Peserta didik juga diberikan penanaman sikap (afektif) agar memahami penilaian baik buruk, benar salah sehingga mampu membedakan segala sesuatu yang berguna atau merugikan bagi diri sendiri, orang lain, terlebih khusus bagi bangsa dan negaranya. Yang terakhir peserta didik dilatih keterampilannya (psikomotorik) sehingga memiliki kemampuan dalam melakukan tugas dan tanggungjawab yang dipercayakan oleh Tuhan Yesus yang berkaitan dengan diri sendiri, orang lain, bangsa dan negaranya. ${ }^{23}$

\section{Kesimpulan}

Jika dicermati maka nyatalah bahwa Pendidikan Agama Kristen memang didesain berdasarkan kebenaran Alkitab, yang mana setiap peserta didik harus diperhadapkan kepada kebutuhan akan Yesus Kristus sebagai Juruselamat yang dapat memperbaharui kehidupan para peserta didik, dalam hal ini pemuda-pemudi yang sedang belajar. Alkitab sebagai sumber utama pendidikan dalam proses belajar mengajar memberitahu bahwa anak-anak muda membutuhkan Roh Kudus untuk mengubah karakter meereka, sehingga

\footnotetext{
${ }^{20}$ Rifai. Guru Pendidikan Agama Kristen SMP Negeri 1 Surakarta \& SMP Negeri 17 Surakarta \& Dosen Teologi STT INTHEOS Surakarta, 1

${ }^{21}$ Nico Syukur Dister, Filsafat Agama Kristen (Yogyakarta: Penerbit Kanisius, 1985), 24.

${ }^{22}$ Boediono - Kepala Badan Penelitian dan Pengambangan Pendidikan Dasar dan Menengah,

Standar Kompetensi Mata Pelajaran Pendidikan Agama Kristen Kurikulum 2004 (Jakarta: Departemen Pendidikan Nasional, 2003), 6.

${ }^{23}$ Ibid, 7
} 
anak-anak muda dapat menjadi generasi penerus yang berkarakter Kristus untuk membangun Indonesia ke depan menjadi Indonesia yang tangguh sesuai Visi Indoensia 2045, sehingga kita melihat bahwa Generasi Emas Indonesia di tahun 2045 dapat terwujud melalui Pendidikan Agama Kristen yang mumpuni

\section{Referensi}

Ahid, Nur. Makalah Pengembangan Kurikulum Pendidikan Karakter, Jakarta: Institut Agama Islam Tribakti, 2013.

Boediono - Kepala Badan Penelitian dan Pengambangan Pendidikan Dasar dan Menengah, Standar Kompetensi Mata Pelajaran Pendidikan Agama Kristen Kurikulum 2004, Jakarta: Departemen Pendidikan Nasional, 2003.

Dister, Nico Syukur. Filsafat Agama Kristen, Yogyakarta: Penerbit Kanisius, 1985.

Hamalik, Oemar. Proses belajar Mengajar, Bandung : Bumi Aksara, 2001.

Wibowo, Agus. Pendidikan Karakter: Strategi Membangun Karakter Bangsa Berperadaban, Yogyakarta: Pustaka Pelajar, 2012.

Rifai. Guru Pendidikan Agama Kristen SMP Negeri 1 Surakarta \& SMP Negeri 17 Surakarta

Siahaan, Harls Evan R. "Aktualisasi Pelayanan Karunia Di Era Digital," EPIGRAPHE: Jurnal Teologi dan Pelayanan Kristiani 1, no. 1 (2017): 23-38, www.stttorsina.ac.id/jurnal/index.php/epigraphe.

Sukmadinata, Nana Syaodih. Kurikulum \& Pembelajaran Kompetensi, Bandung: Kusuma Karya, 2004

https://databoks.katadata.co.id/datapublish/2018/05/18/2018-jumlah-penduduk-indonesiamencapai-265-juta-jiwa

https://www.bps.go.id/statictable/2014/09/05/1366/luas-daerah-dan-jumlah-pulau-menurutprovinsi-2002-2016.html

http://www.netralnews.com/news/rsn/read/71459/di.indonesia.ada.1340.suku.bangsa.dan.3 00.kelompok.etnik

https://cerdasberkarakter.kemdikbud.go.id/

https://www.kemdikbud.go.id/main/blog/2017/07/penguatan-pendidikan-karakter-jadipintu-masuk-pembenahan-pendidikan-nasional.

http://ppidunia.org/2018/08/27/pesan-untuk-pemuda-indonesia-gagas-visi-indonesia-2045bersama-diaspora/ 